\title{
SEED MEDIATED SYNTHESIS OF HEXAGONAL S- DOPED ZnO NANOROD AND ITS PHYSICAL PROPERTIES
}

\author{
Yolanda Rati ${ }^{1}$, Akrajas Ali Umar ${ }^{2}$, Yanuar Hamzah ${ }^{1}$, Ari Sulistyo Rini ${ }^{1}{ }^{1 *}$ \\ ${ }^{1}$ Jurusan Fisika, Fakultas Matematika dan Ilmu Pengetahuan Alam, Universitas Riau, Kampus Bina Widya, Jl. \\ H.R Soebrantas, Km. 12,5 Sp. Baru 28293, Panam, Tampan, Pekanbaru, Riau, Indonesia \\ ${ }^{2}$ Institute of Microengineering and Nanoelectronics, University Kebangsaan Malaysia, Bangi 43600, Selangor, \\ Malaysia \\ *Corresponding Author Email: ari.sulistyo@lecturer.unri.ac.id
}

Received: 12 September 2020

Revised: 18 December 2020

Accepted: 2 February 2021

Online: 28 April 2021

Published: 30 April 2021

SPEKTRA: Jurnal Fisika dan Aplikasinya

p-ISSN: 2541-3384

e-ISSN: 2541-3392

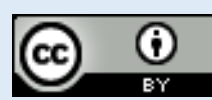

\begin{abstract}
Sulfur-doped zinc oxide ( $\mathrm{S}-\mathrm{ZnO})$ nanorod has been successfully synthesized via the seed-mediated hydrothermal method with different sulfur concentrations $(0 \%, 1 \%, 2.5 \%)$. This research aims to study the influence of the concentration of sulfur on the structure, morphology, and optical properties of $\mathrm{ZnO}$ as a promising material in a wide range of applications. Crystal structure, morphology, and optical properties of the samples were characterized using X-Ray Diffraction (XRD), Field Emission Electron Scanning Microscopy (FESEM), and UV-Vis Spectroscopy, respectively. The XRD pattern shows the strongest peak at $2 \theta=34.43^{\circ}$ for crystal orientation of (002). The crystallinity properties of the $\mathrm{S}-\mathrm{ZnO}$ sample are higher compared to the $\mathrm{ZnO}$ sample. The FESEM images of the $1 \% \mathrm{~S}-\mathrm{ZnO}$ sample exhibit the highest nanorod density arrangement. The optical absorbance of the higher sulfur dopant possesses a higher optical absorption peak on the UV-Vis spectrum. The results indicate that $\mathrm{S}$ doping to $\mathrm{ZnO}$ can alter the structural, morphological, and optical properties of $\mathrm{ZnO}$.
\end{abstract}

Keywords: $\mathrm{ZnO}$ nanorod, sulfur doping, hexagonal, seed-mediated hydrothermal 


\section{INTRODUCTION}

$\mathrm{ZnO}$ (zinc oxide) with one-dimensional (1-D) nanostructures have attracted much attention in recent years due to its wide potential applications. The potential applications of $\mathrm{ZnO}$ nanostructures have been popular in various areas such as solar cells [1], photocatalysis [2], piezoelectric [3], biosensors, and gas sensors [4]. Zinc oxide is a combined semiconductor of IIB-VIA with an energy band gap of $3.37 \mathrm{eV}$ and an exciton binding energy of $60 \mathrm{meV}$. This binding energy is more significant than thermal energy at room temperature, making it applied in UV-blue light emission and room temperature UV amplifiers [5]. ZnO semiconductors are materials that have excellent chemical and thermal stability and are environmentally friendly. $\mathrm{ZnO}$ research is still being developed to obtain an optimum optical, electrical, and structural property for a particular application in various fields. Introducing an impurity into semiconductor material can alter the material's properties, such as its conductivity, transparency, and charge mobility. $\mathrm{ZnO}$ has been doped by metallic such as $\mathrm{Ni}$ [6], Mn [7], $\mathrm{Au}$ [8], $\mathrm{Al}$ and $\mathrm{Mg}$ [9], and non-metallic elements, e.g., C [10], F [11], and S [12]. Sulfur has similar physical and chemical properties to oxygen. However, the bandgap energy of $\mathrm{ZnS}$ ( $3.66 \mathrm{eV}$ ) is much higher than $\mathrm{ZnO}(\sim 3.37 \mathrm{eV})$. Doping of $\mathrm{S}$ (sulfur) into $\mathrm{ZnO}$ has been reported to able to influence the structure of the $\mathrm{ZnO}$ and increase light absorption [13] and improve the electrical and optical properties of $\mathrm{ZnO}$ [14].

In this research, pristine and $\mathrm{S}$-doped $\mathrm{ZnO}$ nanorod thin film was prepared with various percentages of $S(1 \%$ and $2.5 \%)$ via the seed-mediated hydrothermal method. The physical properties of $\mathrm{S}-\mathrm{ZnO}$ samples were analyzed from the results of XRD characterization, FESEM, and UV-Vis spectrophotometer. The addition of sulfur into $\mathrm{ZnO}$ has improved the structural, morphological, and optical properties of $\mathrm{ZnO}$ nanorods.

\section{METHOD}

\section{Chemical material}

The chemicals used in this research, such as zinc acetate dihydrate $\mathrm{Zn}\left(\mathrm{CH}_{3} \mathrm{COO}\right)_{2} .2 \mathrm{H}_{2} \mathrm{O}$, zinc nitrate hexahydrate $\mathrm{Zn}\left(\mathrm{NO}_{3}\right)_{2} .6 \mathrm{H}_{2} \mathrm{O}$, hexamethylenetetramine (HMT) $\left(\mathrm{CH}_{2}\right)_{6} \mathrm{~N}_{4}$, sodium sulfide $\mathrm{Na}_{2} \mathrm{~S}$, ethanol absolute $\mathrm{C}_{2} \mathrm{H}_{5} \mathrm{OH}$, and deionized water $\left(\sim 18^{\Omega}\right)$.

\section{ZnO and S-ZnO Thin Films Synthesis}

The thin film of the S-ZnO nanorod was synthesized using the seed-mediated hydrothermal technique. This method consists of two steps, namely $\mathrm{ZnO}$ seeding and $\mathrm{S}-\mathrm{ZnO}$ growth. The seeding stage begins with making a seeding solution, that is, dissolving zinc acetate dihydrate in absolute ethanol with a concentration of $10 \mathrm{mM}$. The spin coating process was then carried out on the FTO substrate with a speed of $3000 \mathrm{rpm}$ for 30 seconds. The sample was then heated using a hot plate at a temperature of $100^{\circ} \mathrm{C}$ for 15 minutes to produce $\mathrm{ZnO}$ seed. The growth solution was prepared by dissolving $5 \mathrm{~mL}$ of Zinc Nitrate Hexahydrate $50 \mathrm{mM}, 5 \mathrm{~mL}$ Hexamethylenetetramine $50 \mathrm{mM}$, and $0.25 \mathrm{~mL}$ of $\mathrm{Na}_{2} \mathrm{~S}$ in DI Water. The $\mathrm{ZnO}$ seed was then immersed in a synthesis bottle containing the growth solution. The growth process was 
proceeding at a temperature of $90^{\circ} \mathrm{C}$ for $5 \mathrm{~h}$. Finally, the sample was taken out and cleaned using DI Water. The physical properties of the S-ZnO sample were characterized using an Xray diffractometer (7000 Shimadzu Diffractometer), Field Emission Scanning Electron Microscopy (FESEM, ZEISS MERLIN), and UV Vis spectrophotometer (HITACHI U3900H).

\section{RESULTS AND DISCUSSION}

The crystal structure of the $\mathrm{ZnO}$ and $\mathrm{S}-\mathrm{ZnO}$ thin films is known from the results of XRD characterization. FIGURE 1 shows the $\mathrm{X}$-ray diffraction pattern from $\mathrm{ZnO}$ and $\mathrm{S}-\mathrm{ZnO}$ samples. The XRD pattern results show diffraction peaks found at an angle of $2 \theta=34.43^{\circ}$; $36.26^{\circ} ; 37.80^{\circ} ; 47.54^{\circ}$ and $51.62^{\circ}$. The matching results show the diffraction peaks of the hexagonal wurtzite $\mathrm{ZnO}$ crystal structure corresponding to the crystal plane (002), (101), and (102) based on data from Crystallography Open Database (COD) No. 96-210-7060. In addition to the $\mathrm{ZnO}$ phase, there is also an FTO crystal field symbolized by $*$. The diffraction peaks of the FTO are seen in pure ZnO samples and are further weakened by the addition of sulfur atoms to $\mathrm{ZnO}$.

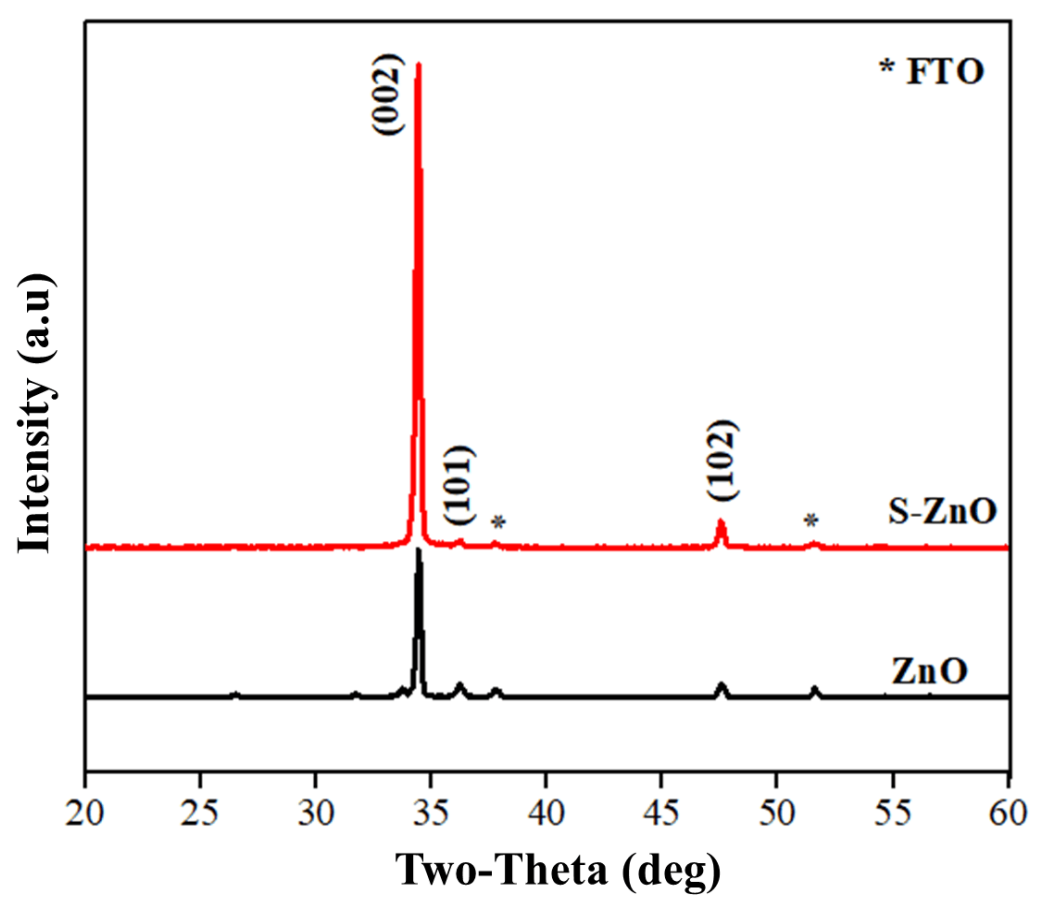

FIGURE 1. XRD Pattern of $\mathrm{ZnO}$ and $\mathrm{S}-\mathrm{ZnO}$ Sample

The diffraction peaks of S-ZnO samples showed high intensity (sharp peaks) compared to pure $\mathrm{ZnO}$ samples, thus giving high crystalline properties. These results are following research conducted by Khan et al. [13]. The highest diffraction peak (strongest line) is in the crystal plane (002) which is in line with the study of Polsongkram et al $(\mathrm{a}=\mathrm{b}=3,249 \AA$ and $\mathrm{c}=5,264$ $\AA$ ) [15]. This shows that the orientation of $\mathrm{ZnO}$ nanorod growth is in the direction of the caxis, which is perpendicular to the surface of the FTO substrate. The $\mathrm{ZnO}$ and $\mathrm{S}-\mathrm{ZnO}$ samples 
crystallite sizes are $38.077 \mathrm{~nm}$ and $38.565 \mathrm{~nm}$, respectively, which were calculated using the Scherrer equation.

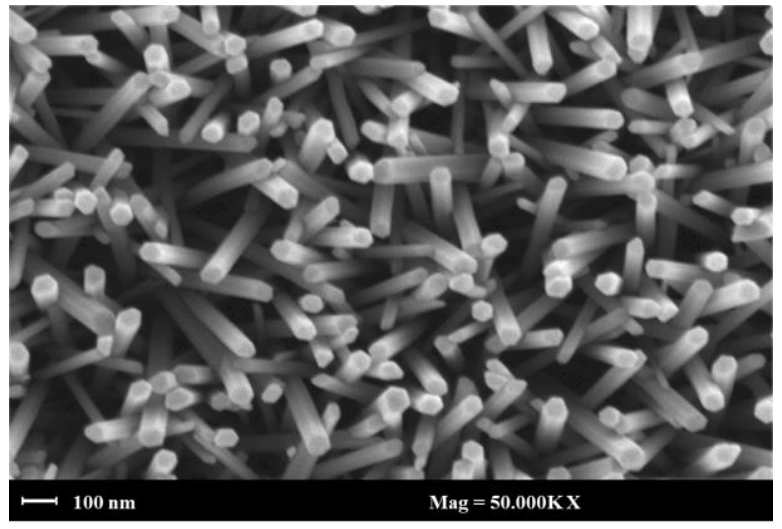

(a)

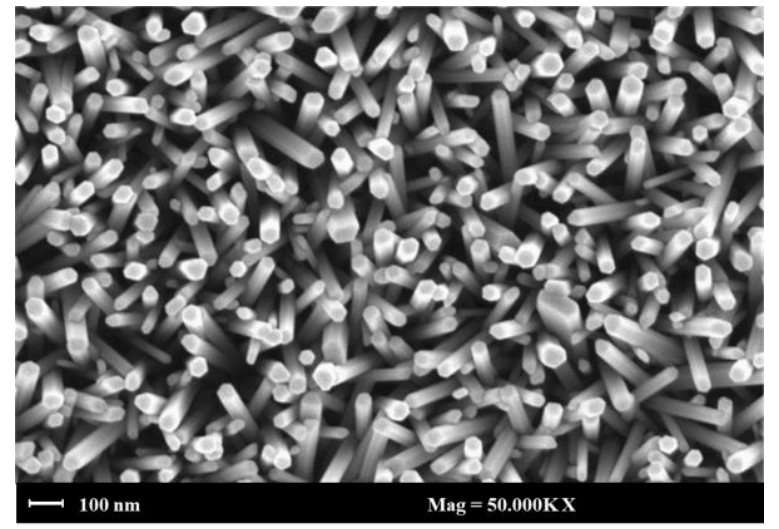

(b)

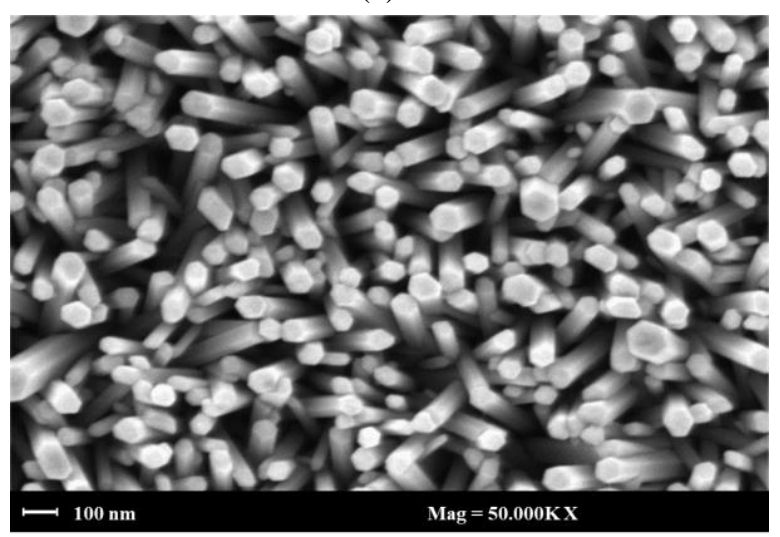

(c)

FIGURE 2. The Photo FESEM of (a) ZnO pure, (b) $1 \% \mathrm{~S}-\mathrm{ZnO}$ and (c) $\mathrm{S}-\mathrm{ZnO} 2.5 \%$

FIGURE 2 shows the FESEM images of the resulting rodlike nanostructure as the concentration of sulfur increased. The geometric shape of the pure $\mathrm{ZnO}$ and $\mathrm{S}-\mathrm{ZnO}$ samples are nanorods with a hexagonal cross-section. FIGURE 2a shows FESEM images of pure ZnO nanorods with a diameter of $42.1+5.6 \mathrm{~nm}$. In addition of $1 \%$ sulfur $(1 \% \mathrm{~S}-\mathrm{ZnO})$, the nanorod diameter tends to decrease with a more uniform size distribution. As the concentration of sulfur increased up to $2.5 \%$ (2.5\% S-ZnO) (FIGURE 2c), a larger diameter was observed with poor size distribution. It suggests that the small addition of $\mathrm{S}$ atoms to $\mathrm{ZnO}(1 \%-\mathrm{S})$ has changed the diameter and shape of nanorods. A similar result has been observed by Khan et al.

The optical properties of the $\mathrm{ZnO}$ and $\mathrm{S}-\mathrm{ZnO}$ thin film samples can be known from the UVVis absorbance spectrum in FIGURE 3. The absorbance spectrum results show the optical absorption peaks occur in the wavelength range of 300-380 nm in the UV light spectrum. While in the visible light spectrum (380-800 $\mathrm{nm})$, the optical absorption that occurs is weak. The optical absorption peak at a wavelength of $378 \mathrm{~nm}$ is in accordance with the $\mathrm{ZnO}$ nanorod reference [16]. Based on the UV-Vis absorbance spectrum, the absorption of S-ZnO samples increases with the addition of the $\mathrm{S}$ composition to $\mathrm{ZnO}$. This increase in absorbance value 
indicates the thickness of the sample, which increases with the addition of $\mathrm{S}$ atoms. The more non-transparent the sample shows that more $\mathrm{ZnO}$ molecules are produced so that the light absorbed will increase.

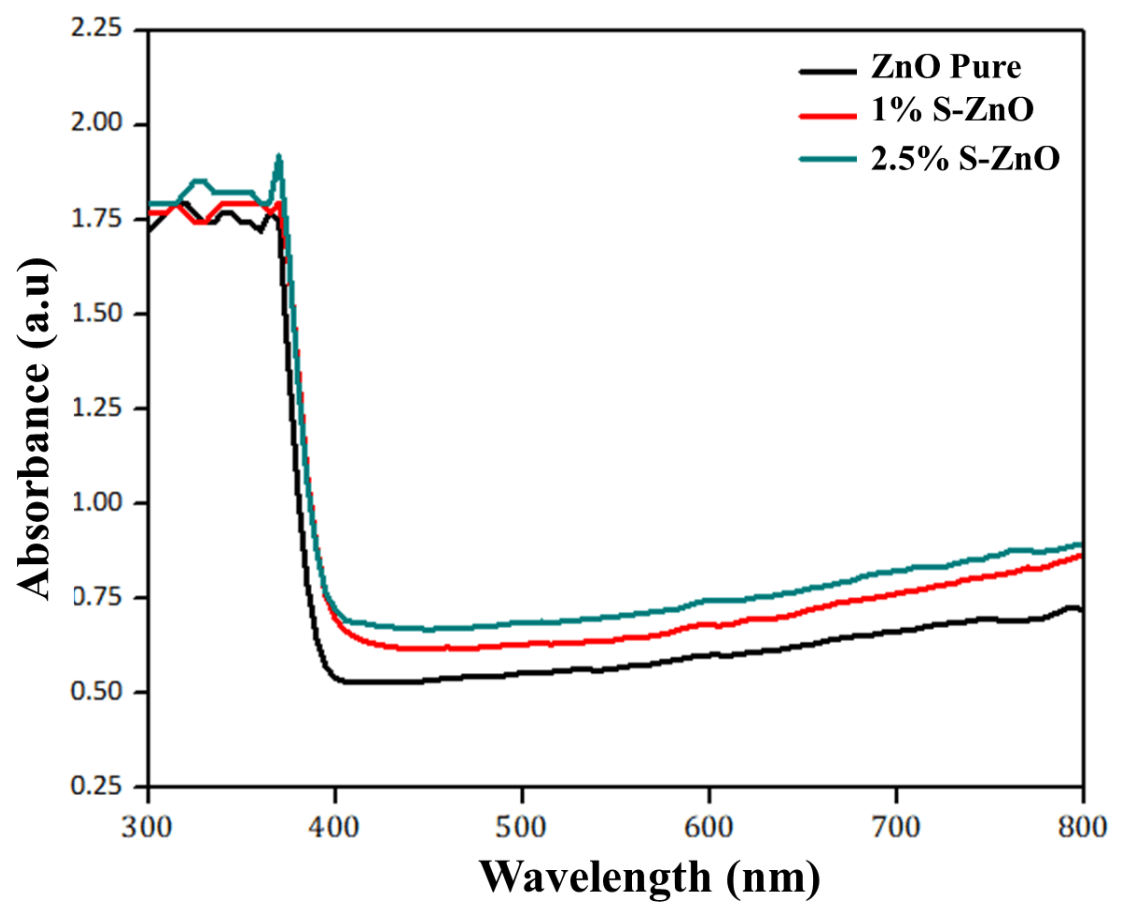

FIGURE 3. UV-Vis Absorbance Spectrum of Thin Film ZnO and S-ZnO

\section{SUMMARY}

Thin films of S-ZnO nanorod were successfully grown on FTO using the seed-mediated hydrothermal technique. XRD characterization shows that the addition of elemental sulfur can increase the crystalline size of $\mathrm{ZnO}$ from $38.077 \mathrm{~nm}$ to $38.565 \mathrm{~nm}$. The morphology shown from the results of FESEM with the addition of sulfur atoms gives a higher density of nanorod growth, especially in the $1 \% \mathrm{~S}-\mathrm{ZnO}$ sample. The results of $\mathrm{UV}$-Vis absorbance spectra showed that the absorption peak had increased at sample $2.5 \% \mathrm{~S}-\mathrm{ZnO}$. Based on the crystal structure, morphology, and the level of UV-Vis absorbance from the results of this research, S-doped $\mathrm{ZnO}$ can improve the physical properties of $\mathrm{ZnO}$ so that it can potentially be applied in the fields of photocatalysts, gas sensors, and solar cells.

\section{ACKNOWLEDGMENT}

We thank the Institute for Research and Community Service, the University of Riau. The author also thanks CRIM and the Institute of Microelectronic and Nanoengineering (IMEN), Universiti Kebangsaan Malaysia, for facilitating this research.

\section{REFERENCES}

[1] L. C. Chen and Z. L. Tseng, "ZnO-Based Electron Transporting Layer for Perovskite Solar Cells,” Nanostructured Sol. Cells, pp. 203-215, February 2017. 
[2] E. Hidayanto, H. Sutanto, and K. S. Firdausi, "Pembuatan Lapisan Fotokatalis Zinc Oxide ( $\mathrm{ZnO})$ dengan Teknik Spray Coating dan Aplikasinya pada Pengering Jagung," Berk. Fis, vol. 16, no. 4, pp. 119-124, 2013.

[3] Z. Lin and J. Song, "Piezoelectric Nanogenerators Based on Zinc Oxide Nanowire Arrays Author(s): Zhong Lin Wang and Jinhui Song Source," Science (80), vol. 312, no. 5771, pp. 242-246, 2006.

[4] H. Morkoc and U. Ozgur, "Zinc Oxide: Fundamentals, Materials and Device Technology," in Processing, Devices, and Heterostructures, Federal Republic ofGerman: WILEY-VCH Verlag GmbH \& Co. KGaA, Weinheim, pp. 446-454, 2009.

[5] M. Torabi et al., "We are IntechOpen, the world' s leading publisher of Open Access books Built by scientists, for scientists TOP $1 \%$," Intech, vol. 1, no. tourism, p. 13, 2016.

[6] O. Bayram et al., "Investigation of structural, morphological and optical properties of Nickel-doped Zinc oxide thin films fabricated by co-sputtering," J. Mater. Sci. Mater. Electron, vol. 30, no. 4, pp. 3452-3458, 2019.

[7] G. G. Rusu et al., "Preparation and characterization of Mn-doped ZnO thin films," J. Optoelectron. Adv. Mater, vol. 12, no. 4, pp. 895-899, 2010.

[8] I. Iwantono et al., "Enhanced charge transfer activity in Au nanoparticles decorated ZnO nanorods photoanode," Phys. E Low-Dimensional Syst. Nanostructures, vol. 111, pp. 44-50, 2019.

[9] F. A. Garcés et al., "Structural Analysis of $\mathrm{ZnO}($ : Al,Mg) Thin Films by X-ray Diffraction,” Procedia Mater. Sci, vol. 8, pp. 551-560, November 2015.

[10] A. S. Alshammari et al., "Visible-light photocatalysis on C-doped $\mathrm{ZnO}$ derived from polymer-assisted pyrolysis," RSC Adv, vol. 5, no. 35, pp. 27690-27698, 2015.

[11] R. Jothi Ramalingam et al., "Synthesis, characterization and optical properties of sulfur and fluorine-doped $\mathrm{ZnO}$ nanostructures for visible light utilized catalysis," Optik (Stuttg), vol. 148, pp. 325-331, 2017.

[12] V. Kumari et al., "S-, N- and C-doped $\mathrm{ZnO}$ as semiconductor photocatalysts: A review," Front. Mater. Sci, vol. 13, no. 1, pp. 1-11, 2019.

[13] A. Khan et al., "A novel fabrication methodology for sulfur-doped $\mathrm{ZnO}$ nanorods as an active photoanode for improved water oxidation in visible-light regime," Nanotechnology, vol. 28, no. 5, pp.1-9, 2017.

[14] E. Maryanti, "Sintesis Mikro Partikel ZnO Terdoping Sulfur Alam ( ZnO : S ) Melalui Metode Mechanochemical," pp. 137-142, 2013.

[15] D. Polsongkram et al., "Effect of synthesis conditions on the growth of $\mathrm{ZnO}$ nanorods via hydrothermal method," Phys. B Condens. Matter, vol. 403, no. 19-20, pp. 37133717, 2008.

[16] Y. Tao et al., "The effect of seed layer on morphology of $\mathrm{ZnO}$ nanorod arrays grown by hydrothermal method," J. Alloys Compd, vol. 489, no. 1, pp. 99-102, 2010. 